\title{
Protogynous Sex Change in the Reed Frog Hyperolius viridiflavus
}

\author{
T. U. Grafe AND K. E. Linsenmair
}

\begin{abstract}
Observations on captive reed frogs Hyperolius viridiflavus ommatostictus showed that seven out of 24 females changed into males. Sex change occurred without any hormone treatment and resulted in completely functional males. The adaptive value is discussed in terms of maximizing life-time reproductive success. Hyperolius r. ommatostictus is the first amphibian known to show functional sex reversal.
\end{abstract}

$\mathrm{S}^{\mathrm{E}}$ EQUENTIAL hermaphroditism has been documented for a few plants (Heslop-Harrison, 1972; Freeman et al., 1980) and is relatively widespread among invertebrate phyla (Giese and Pearse, 1974-1979; Charnov, 1982). In vertebrates sequential hermaphroditism, both protandry (male first) and protogyny (female first), has been found only in fishes (Smith, 1975; Shapiro, 1984; Warner, 1988). Many authors (Warner, 1978; Charnov, 1982; Policansky, 1982) have speculated that sex change should be more common than existing data indicate.

We observed protogynous sex change in a laboratory raised population of the reed frog Hyperolius viridiflavus ommatostictus (for discussion of systematic status see Schiøtz, 1971, 1975; Drewes, 1984; Poynton and Broadley, 1987); this subspecies occurs in East Africa between Mt. Kilimanjaro and Mt. Mero (Schiøtz, 1975). The "superspecies" $H$. viridiflavus is found in most of sub-Saharan Africa. More than 50 subspecies have been recognized (Schiøtz, 1971), some of which may be classified as species in the future. They are all more or less well adapted to the harsh environmental fluctuations of the dry and wet seasons of the African savannah. Juvenile frogs are found estivating on plants in exposed positions (Stewart, 1967) and must withstand high temperature and high radiation load. Although they are very small (300-700 $\mathrm{mg}$ ), showing an unfavorable surface to volume ratio, they have to survive for many weeks, in some areas even for several months, on low amounts of water and small energy reserves stored prior to estivation (Geise and Linsenmair, 1986; Kobelt and Linsenmair, 1986). Juveniles attain sexual maturity in $3-10$ mo depending on climatic conditions. Adults, with their different morphological and behavioral adaptations probably cannot survive in areas that experience a pronounced dry season and are probably annual in such areas. In West Africa we have never found adult $H . v$. nitidulus that had survived a dry season and under laboratory conditions adult $H$. viridiflazus ssp. senesce rapidly after breeding activity ends (compare with Richards, 1977).

Schaffer (1974) stated that if in fluctuating environments post-breeding survival is low, selection acts to increase reproductive effort. Our observations on $H . v$ ommatostictus and other studies on life history patterns in Hyla rosenbergi (Kluge, 1981) and Hyperolius concolor (Polder, 1975) confirm that where adult mortality is high, this is correlated with high reproductive effort showing risk sensitivity with large clutches and multiple clutches in one season.

\section{Materials ANd Methods}

In 1985 five male and five female $H . v$. ommatostictus, probably from Kenya, were obtained from a commercial supplier. In the weeks that followed, they successfully deposited multiple clutches. Tadpoles were reared and juvenile frogs kept under dry conditions for 4-6 mo (Geise, 1987).

This $F_{1}$-generation was later transferred to terraria with more humid conditions where they experienced accelerated growth and sexual maturity. We kept $H$. v. ommatostictus in terraria $(80 \times 60 \times 50 \mathrm{~cm})$ containing plants such as Rhaphidophora, Spatophyllum and Tradescantia rooted in a $5-10 \mathrm{~cm}$ layer of clay. To stimulate breeding activity the terraria were flooded so that parts of the plants were under water. Terraria were occupied with 15-20 adults of varying sex ratios. Frogs were fed ad lib on a diet of Drosophila, Musca and Lucillia from our own culture. Frogs were measured (SVL) and weighed (Mettler balance AE 163) at regular intervals. Temperature varied between $22 \mathrm{C}$ 
Table 1. Schedule of Sex Change Showing Time Periods between Last Clutch Laid, Onset of Male BEHAVIOR AND FERTILIZATION OF EgGS BY INDIVIDUAL Sequential Hermaphrodites.

\begin{tabular}{|c|c|c|c|c|}
\hline & \multirow[b]{2}{*}{$\begin{array}{l}\text { Number } \\
\text { of } \\
\text { clutches }\end{array}$} & \multicolumn{2}{|c|}{ Number of days spent between } & \multirow[b]{2}{*}{ Total } \\
\hline & & $\begin{array}{l}\text { Last clutch } \\
\text { and first signs } \\
\text { of male } \\
\text { behavior }\end{array}$ & $\begin{array}{c}\text { First male } \\
\text { behavior and } \\
\text { fertilization rate } \\
\text { of } 70 \%\end{array}$ & \\
\hline$\oint 1$ & 3 & 3 & 52 & 55 \\
\hline ఫे? & 1 & 23 & 83 & 106 \\
\hline ఫే3 & 0 & - & $32(37 \%)$ & - \\
\hline$\$ 4$ & 1 & 77 & - & - \\
\hline$\$ 5$ & 2 & 25 & 33 & 58 \\
\hline$\$ 6$ & 3 & 64 & - & - \\
\hline òt7 & 3 & 26 & - & - \\
\hline
\end{tabular}

(night) and 32-35 C (day), being highest at the top of the terraria nearest to the mercury vapor lamps $(125 \mathrm{~W})$, that were operated on a $12.5 \mathrm{~h}$ light cycle.

Adult $H$. v. ommatostictus show distinct individual coloration patterns enabling us to monitor behavior of individuals. Observations were conducted during the first half of the night for the length of the breeding season that we simulated from Sept. 1986 until April 1987.

Hyperolius $v$. ommatostictus is a prolonged breeder and males typically defend calling sites and maintain individual spacing in the chorus (Geise, 1987; compare with Telford, 1985). Male-male combat is of considerable intensity (Wager, 1965; Stewart, 1967). Females approach males and initiate amplexus. Eggs are laid on vegetation under water.

Females and males in amplexus were monitored and eggs later removed from the terraria, counted and fertilization rates determined. To test if sex reversed females were capable of fertilizing eggs, they were placed in a separate terrarium with females that were ready to oviposit.

\section{Results}

Signs of sex change were apparent 2 mo after females had laid their first clutches. Three females started to assume male calling posture during peak calling activity. In the beginning females could not produce any sounds, but their vocal sacs soon developed and they started to give both advertisement and aggressive calls of normal call duration and call rate and engaged in long fighting bouts with primary males, thus

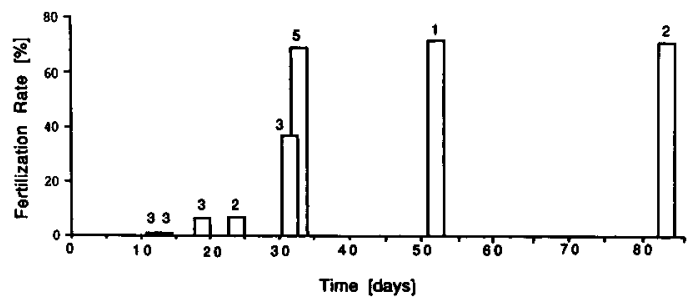

Fig. 1. Fertilization rates of secondary males in days after appearance of first male behavior. Numbers designate individuals.

showing the main elements of male behavioral repertoire.

Sex reversal took 3-77 d measured from last clutch laid until time of first calling behavior. Seven out of 24 females eventually changed sex, out of which six had been observed laying 1-3 clutches of eggs (Table 1). This is a conservative count, because females may have laid additional clutches that we could not assign to individual females and this may explain the aforementioned high variance in time between last clutch laid and first observation of male behavior. The average clutch size of hermaphrodites $(\bar{x}=341.3$ $\pm 171.2, \mathrm{n}=9$ ) was not significantly different from that of "normal" females $(\bar{x}=332.3 \pm$ $137.5, \mathrm{n}=30$; U-test $P>0.05$ ).

Four hermaphrodites (secondary males) went into amplexus (1-4 times) with females and successfully fertilized eggs. Fertilization rates increased with time (Fig. 1) and reached $70 \%$ in 5-12 wk after male behavior started, which were still lower than fertilization rates of primary males $(\bar{x}=86 \pm 20 \%, \mathrm{n}=29)$.

Recently we have also observed protogynous sex change of two female $H$. $v$, taeniatus (syn. $H$. marmoratus taeniatus; Poynton, 1985) kept under similar conditions as for $H$. . ommatostictus. One other female died without showing any behavioral signs of sex change. Dissection showed that its gonads were in a transitional state (Fig. 2). These additional observations may indicate that protogynous sex change is a life history tactic found also in other $H$. viridiflavus ssp.

\section{Discussion}

Gonadectomy, parabiosis and hormone treatment have led to complete sex reversal in many species of anurans and urodeles (Schmid, 1983; Adkins-Regan, 1987). A well known example of the effects of gonadectomy is found in Bufo 


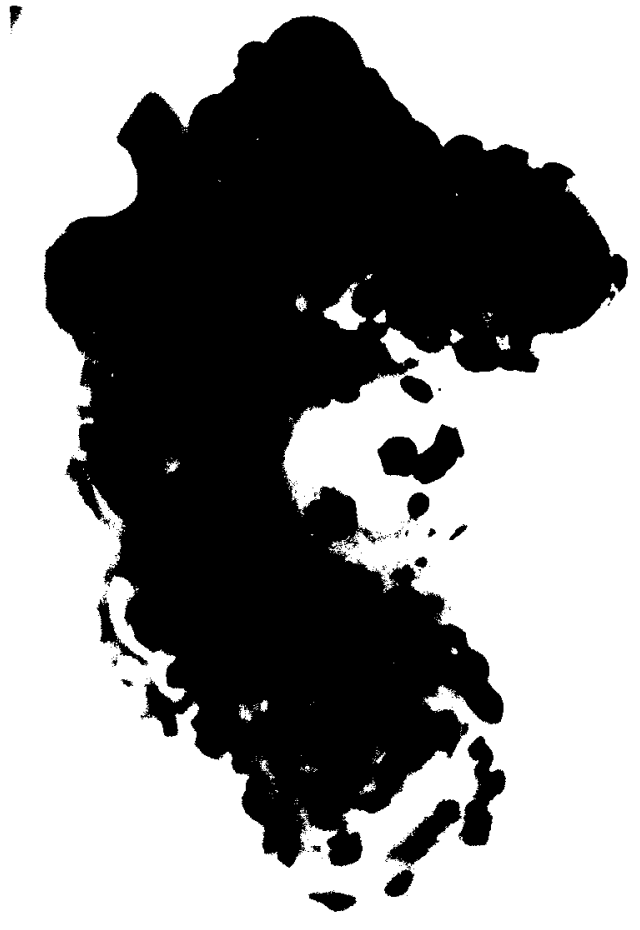

Fig. 2. Left ovotestis of a Hyperolius viridiflavus taeniatus individual showing black ovarian tissue and a white testicular nodule $(45 \times)$.

bufo. Removal of the testes of sexually mature males is followed by the development of the Bidder's organ into functional ovaries (Gallien, 1965). Hormone treatment, either by injection or by addition to the aquarium water of the tadpoles, has been used successfully to change sex in a number of amphibians. Richards (1982) for example treated tadpoles of $H$. $v$. viridiflavus with testosterone, which led to a complete masculinization of the gonads. Other environmental extremes like extreme temperatures or egg hypertrophy can also override the genetic sex determining mechanisms thought to be prevalent in amphibians (Bull, 1983).

To our knowledge no account has been published on functional sex reversal in amphibians under natural conditions, nor in the laboratory, without the kinds of experimental treatments discussed above. Many authors have reported cases of abnormality in the reproductive system of amphibians found in the field (Crew, 1921; Witschi, 1930; Moore, 1944) and Witschi (1923) gave an account of simultaneous hermaphroditism in Rana temporaria where two frogs had well developed ovaries and testicular nodules with fertile eggs and spermatozoa; however, no behavioral or life history data indicating that this occurs in the field were provided. Crew (1921) actually found a $R$. temporaria with typical male secondary sexual characteristics in amplexus with a female and later showed by dissection that this individual had two ovotestes structured like normal testes with only a few degenerate ova included. All offspring from his breeding experiment were female, showing that this individual, although behaving and functioning as a male, was probably a genetic female. There is no indication that this individual ever reproduced as a female.

In general, protogynous hermaphroditism should be selected for if an individual maximizes its lifetime reproductive success by breeding as a female first and as a male later on. Protogyny is favored under three conditions. First, when there is differential male reproductive success that is age or size specific (Ghiselin, 1969; Warner, 1975; Charnov, 1982). This is facilitated by high levels of male-male competition and/or pronounced female choice for larger males. Under these conditions a few males can monopolize all the matings and achieve a much higher reproductive success than any female could. A female changing into such a male age or size class could achieve a profound advantage.

Second, protogyny should be selected for if female residual reproductive success stays constant or decreases with age or size relative to male residual reproductive success (Ghiselin, 1969; Warner, 1975; Charnov, 1982). Although female fecundity is size related in most fishes and amphibians (which show indeterminate growth), situations may arise in a fluctuating environment where the absence of an essential nutrient may decrease considerably female reproductive output. Such a situation is analogous to sex ratio adjustment according to food abundance found in a comparative study of alligators in nature and in farms (Nichols and Chabreck, 1980) and mammals (Clutton-Brock and Albon, 1982).

Finally, protogynous sex reversal could be favored if mortality is sex dependent, with mature males incurring much higher mortality than females. The first part of life should be spent as the sex with the lowest mortality rate, in this case as a female (Charnov, 1982). Field data on highly vocal anurans indicate that males indeed incur higher mortality due to acoustically hunting predators (Kluge, 1981; Ryan et al., 1982).

Sex change should be a result of an interac- 

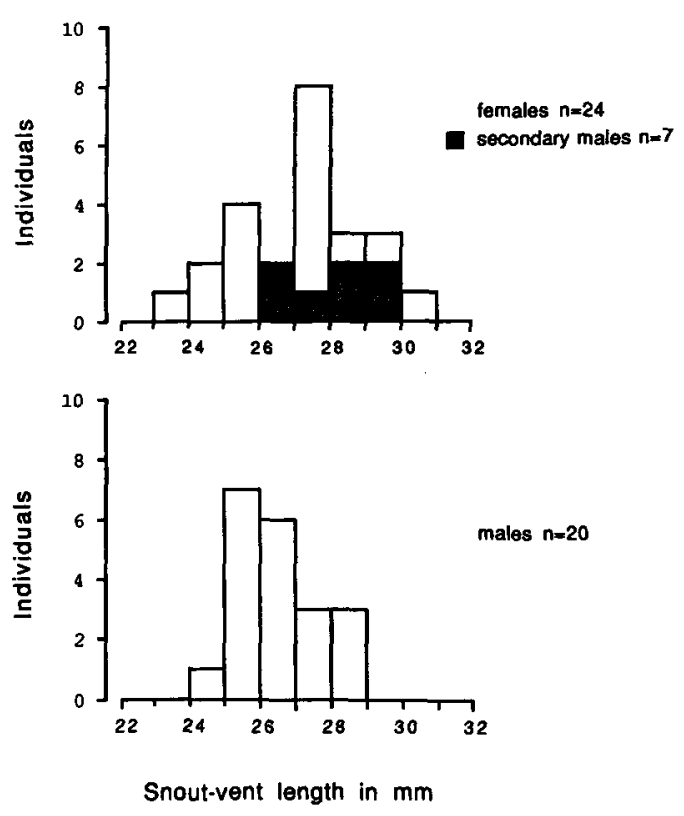

Fig. 3 Size distribution of males, females and secondary males.

tion of sex specific mating patterns, fecundity and survival characteristics. Our preliminary data on sex reversal in $H$. $v$. ommatostictus are in accordance with theoretical predictions. There was no significant size difference between primary males and females and although there was also no significant difference between females that changed sex and those that did not, the larger females tended to change sex (larger sample size may establish this trend). As a result, a significant size difference existed between secondary and primary males (U-test, $P<0.05$ ), probably favoring males in intrasexual competition and allowing them to attain a higher residual reproductive success than if they had remained female (Fig. 3). This size advantage could be further facilitated by recruitment of progeny gaining sexual maturity during the breeding season of the parental generation. These individuals can be up to $20 \%$ smaller than their parents (Geise, 1987). According to Telford et al. (1988) the closely related $H$. marmoratus shows a large male mating advantage in very small choruses.

Second, laboratory conditions may have affected specific nutritional needs of females in such a way as to reduce female fecundity. We do not believe that sex reversal is purely a laboratory artifact because of the completeness of sex change showing no pathological traits. Fur-
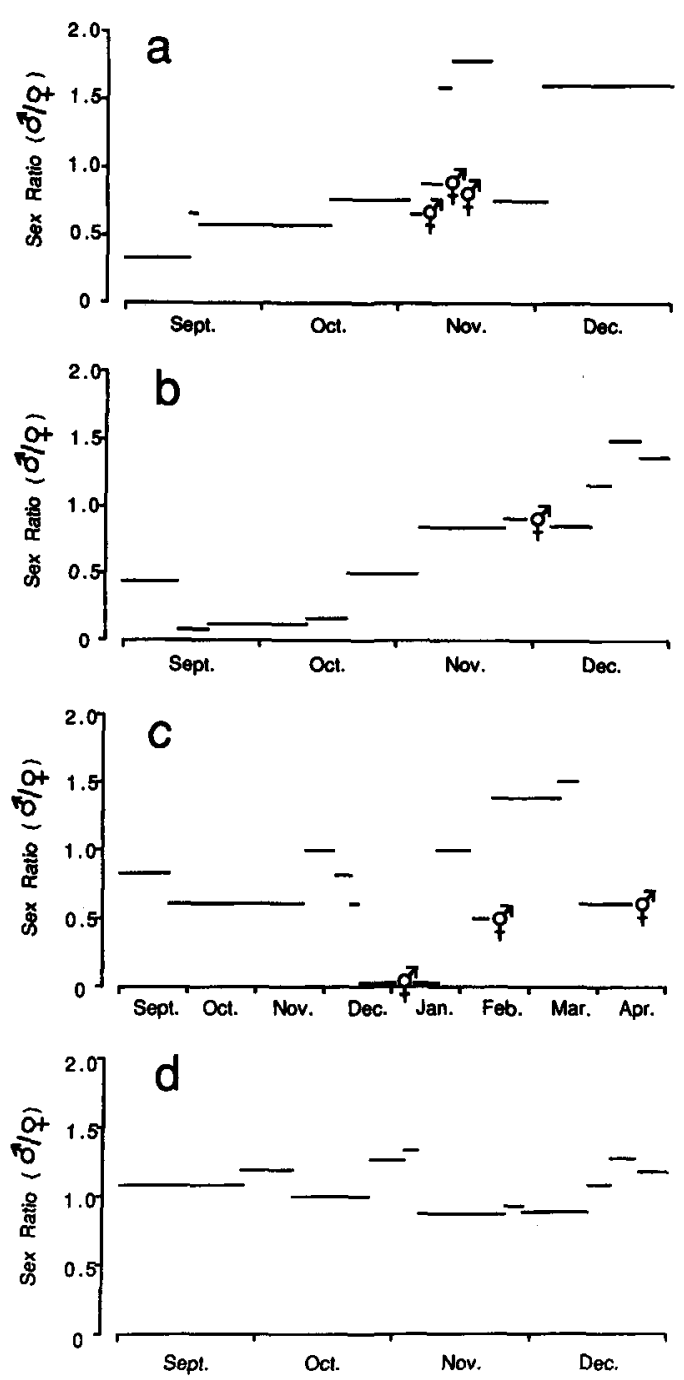

Fig. 4. Appearance of hermaphrodites, based on first signs of male behavior, in terraria (a-d) showing different sex ratios over time. Fluctuations in sex ratio were due to mortality or addition of frogs.

thermore specific nutritional demands cannot be the sole factor because only certain females changed sex, namely those that tended to be larger and only in certain terraria, which did not differ in regard to the diet offered.

Finally, in those terraria in which male density was low or dropped during the breeding season, we found a disproportionate number of females changed into males (Fig. $4 a-c)$. In one terrarium where male density was high, no females changed sex (Fig. 4d). This indicates that females may assess male density and respond by 
turning into males, thus adaptively reshaping changes in demography.

Could the females mated to secondary males have used sperm stored from a previous mating? In the tailed frog Ascaphus truei, which has internal fertilization, females have been shown to retain viable sperm (Metter, 1964). In anurans showing external fertilization like $H$. v. ommatostictus, there is no indication that females have any form of sperm retention or storage. Especially in species with aquatic oviposition, it is hard to imagine sperm moving up the cloaca of the female to be stored for later use.

The question concerning the adaptive value of sex reversal in $H$. v. ommatostictus, and the significance of different selective pressures as discussed above, must stay unanswered until the necessary field data are available. The length of time for sex reversal to be completed (2-3 mo, Table 1) seems extremely long for an annual species with only one breeding season. Under these constraints sex reversal is adaptive only in a lengthy breeding season. Telford (1982) observed continuous breeding activity of H. marmoratus for a 7 mo period. This seems long enough for females to successfully offset time lost for breeding during sex change through an increase in residual reproductive success as a male later on. Also sex reversal could probably take less time in the field. We consider times reported here to be maximum times since some females may have laid an additional unobserved clutch just prior to showing male behavior and high fertilization rates may have been reached sooner in some hermaphrodites (e.g., \#1 and \#2), had they been tested earlier.

This is the first report of functional sex change in any anuran where the same individual successfully reproduced as a female and as a male. If sex reversal is confirmed in the field, interesting new comparative work between taxa could emerge. Anurans especially would offer challenging new insights into ecological, endocrinological and neurophysiological problems of sex change.

\section{ACKNOWLEDGMENTS}

We thank W. Geise and R. Schmuck for assistance during this study. K. Adler, W. Geise and M. M. Stewart made helpful comments on an earlier draft. This work was supported by the Deutsche Forschungsgemeinschaft grant \#Li 150/11-1,2.

\section{Literature Cited}

Adkins-Regan, E. 1987. Hormones and sexual differentiation, p. 1-29. In: Hormones and reproduction in fishes, amphibians and reptiles. D. O. Norris and R. E. Jones (eds.). Plenum Press, New York, New York.

Bull, J. J. 1983. Evolution of sex determining mechanisms. The Benjamin Cummings Publishing Company, Inc. Menlo Park, California.

Charnov, E. L. 1982. The theory of sex allocation. Princeton University Press, Princeton, New Jersey.

Clutton-Brock, T. H., And S. D. Albon. 1982. Parental investment in male and female offspring in mammals, p. 223-248. In: Current problems in sociobiology. King's College Sociobiology Group (ed.). Cambridge University Press, Cambridge, United Kingdom.

Crew, F. A. E. 1921. Sex reversal in frogs and toads. J. Genet. 11:141-181.

Drewes, R. C. 1984. A phylogenetic analysis of the Hyperoliidae (Anura): treefrogs of Africa, Madagascar and the Seychelles Islands. Occ. Pap. Calif. Acad. Sci. 139:1-70.

Freeman, D. C., K. T. Harper and E. L, Charnov. 1980. Sex change in plants: old and new observations, and new hypotheses. Oecologia 47:222-232.

Gallien, L. G. 1965. Genetic control of sexual differentiation in vertebrates, p. 583-610. In: Organogenesis. R. L. DeHaan and H. Ursprung (eds.). Holt, Reinhardt \& Winston, New York, New York.

GeISE, W. 1987. Leben unter Extrembedingungen: Untersuchungen zur Ästivationsphysiologie und zur Variabilität im Lebenszyklus beim afrikanischen Riedfrosch Hyperolius viridiflavus (Anura: Hyperoliidae). Unpubl. Ph.D. dissert., Bayerische JuliusMaximilians-Universität Würzburg, Würzburg, Federal Republic of Germany.

—, AND K. E. Linsenmair. 1986. Adaptations of the reed frog Hyperolius viridiflarus (Amphibia, Anura, Hyperoliidae) to its arid environment: II. Some aspects of the water economy of $H$. $v$. nitidulus under wet and dry season conditions. Oecologia 68: 542-548.

GHiselin, M. T. 1969. The evolution of hermaphroditism among animals. Quart. Rev. Biol. 44:189208.

Giese, A. C., ANd J. S. Pearse (eds.). 1974-1979. Reproduction of marine invertebrates, Vol. 1-5, Academic Press, New York, New York.

Heslop-HARRIson, J. 1972. Sexuality of angiosperms, p. 133-290. In: Plant physiology, F. C. Steward (ed.). Vol. 6C. Academic Press, New York, New York.

KLuge, A. G. 1981. The life history, social organization, and parental behavior of Hyla rosenbergi Boulenger, a nest-building gladiator frog. Misc. Publ. Mus. Zool. Univ. Michigan, no. 160.

Kobelt, F., AND K. E. Linsenmair. 1986. Adaptations of Hyperolius viridiflavus (Amphibia, Anura, Hyperoliidae) to its arid environment. I. The skin 
of Hyperolius viridiflarus nitidulus (Laurent) in wet and dry season conditions. Oecologia 68:533-541.

MetTer, D. E. 1964. On breeding and sperm retention in Ascaphus. Copeia 1964:710-711.

MOORE, J. A. 1944. Geographic variation in Rana pipiens Schreber of eastern North America. Bull. Amer. Mus. Nat. Hist., 82:345-370.

Nichols, J. D., And R. H. Chabreck. 1980. On the variability of alligator sex ratios. Amer. Natur. 116 : $125-137$.

Polder, W. N. 1975. Erfahrungen mit Hyperolius Arten. Dtsch. Aquar. Terr. Z. 3:100-103.

PolicANSKy, D. 1982. Sex change in plants and animals. Annu. Rev. Ecol. Syst. 13:471-495.

Poynton, J. C. 1985. On the Hyperolius marmoratus complex (Anura). S. Afr. J. Sci. 81:179-181.

- ANd D. G. Broadley. 1987. Amphibia Zambesiaca 3. Rhacophoridae and Hyperoliidae. Ann. Natal Mus. 28 (1):161-229.

RICHARDS, C. M. I977. Reproductive potential under laboratory conditions of Hyperolius viridiflavus (Amphibia, Anura, Hyperoliidae), a Kenyan reed frog. J. Herpetol. 11:426-428.

- 1982. The alteration of chromatophore expression by sex hormones in the Kenyan reedfrog, Hyperolius viridiflazus. Gen. Comp. Endocrinol. 45:59-67.

Ryan, M. J., M. D. Tuttle and A. S. Rand. 1982. Bat predation and sexual advertisement in a Neotropical frog. Amer. Natur. 119:136-139.

ScHAFFER, W. M. 1974. Optimal reproductive effort in fluctuating environments. Ibid. 108:783-790.

Scніøтz, A. 1971. The superspecies Hyperolius viridiflavus (Anura). Vidensk. Meddr. dansk. naturh. Foren. 134:21-76.

- 1975. The treefrogs of eastern Africa. Steenstrupia, Copenhagen, Denmark.

SCHMID, M. 1983. Evolution of sex chromosomes and heterogametic systems in Amphibia. Differentiation 23 (Suppl.):S13-S22.

Shapiro, D. Y. 1984. Sex reversal and sociodemographic processes in coral reef fishes, p. 103-118. In: Fish reproduction, strategies and tactics. G. W. Potts and R. J. Wooten (eds.). Academic Press, New York, New York.
Sмrтн, C. L. 1975. The evolution of hermaphroditism in fishes, p. 295-310. In: Intersexuality in the animal kingdom. R. Reinboth (ed.). Springer Verlag, Berlin, Federal Republic of Germany.

Stewart, M. M. 1967. Amphibians of Malawi. State University of New York Press, Albany, New York.

TeLford, S. R. 1982. Aspects of mate recognition and social behavior in a sub-tropical frog-community. Unpubl. Ph.D. dissert., University of the Witwatersrand, Johannesburg, South Africa.

. 1985. Mechanisms and evolution of intermale spacing in the painted reedfrog (Hyperolius marmoratus). Anim. Behav, 33:1353-1361.

, M. L. Dyson AND N. I. PAssmore. 1988. Mate choice occurs only in small choruses of painted reed frogs (Hyperolius marmoratus). Bioacoustics 1.

Wager, V. A. 1965. The frogs of South Africa. Purnell and Sons (S.A.) PTY., LTD. Cape Town and Johannesburg, South Africa.

WARNER, R. R. 1975. The adaptive significance of sequential hermaphroditism in animals. Amer. Natur. 109:61-82.

1978. The evolution of hermaphroditism and unisexuality in aquatic and terrestrial vertebrates, p. 78-101, In: Contrasts in behavior. E. Reese (ed.). Wiley Interscience, New York, New York.

1988. Sex change and the size-advantage model. Trends Ecol. Evol. 3:133-136.

Witschi, E. 1923. Über die genetische Konstitution der Froschzwitter. Biol. Zentralbl. 43:83-96.

- 1930. The geographical distribution of the sex races of the European grass frog (Rana temporaria). A contribution to the problem of the evolution of sex. J. Exp. Zool. 56:149-165.

ZOOLOGISCHES INSTITUT DER UNIVERSITÄT, RÖNTGENRING 10, D-8700 WÜRzBURG, FEDeral Republic of Germany. Present Address (TUG): NeURobiology and Behavior, Cornell. University, Ithaca, New York 14853. Accepted 27 Feb. 1989. 